\title{
米国における緊急対応マニュアルの調査 \\ Emergency Response Manuals in U.S.A.
}

西村宏昭 *

Hiroaki NISHIMURA

\section{1. まえがき}

一般社団法人日本風工学会は風災害の低減を活動の一 つに挙げており，竜巻や台風等によって発生した被害の 調査を行い，明らかになった事実やそれらから得られる 教訓をまとめた情報を広く発信している ${ }^{1)}$ 。情報には, 純 粋に技術的な側面と組織や個人の行動に関する側面とが ある。後者の, いわゆるソフトウェアに関する分野は, 自然科学の研究者や技術者加らる本会の多くの会員の 得意とする領域ではない。しかし，強風災害後の被害調 査を続けていくうちに，災害に直面した自治体の緊急対 応マニュアルの整備が希薄であると感じることが少なく なかった。それは本特集『「個人」・「行政」を対象とした 対応マニュアル』でも明らかにされたように，防災基本 計画中の考慮すべき災害の分類に竜巻や台風が挙げられ ていなかったことがあることで分かる。

そこで，竜巻対応マニュアル作成研究会では，米国の 緊急対応マニュアルの整備状況を調査した。米国では, 組織立てされた危機管理体制の中に自然災害への対応が 組み込まれており，多くの組織で，互いに連係された膨 大な量のドキュメントが準備されている。ここでは，米 国における緊急対応マニュアルの一部を調査したので紹 介する。調査した文献はインターネットで検索した。つ まり，多くの緊急対応マニュアルがインターネット上で 公表されており，容易に手に入れることができる。ただ し，これらのドキュメントは必ずしも最新版ではないが,
基本的な内容は変わらないと思われる。

最初に, 最も広い範囲をカバーするアメリカ合衆国国 土安全保障省の国家対応計画を紹介寸る。これはわが国 における内閣府の防災基本計画に相当するであろう。次 にフロリダ州の緊急管理計画を，さらにその下の Miami Dade 郡の緊急管理計画を紹介する。これらは，わが国の 都道府県単位および市町村単位の地域防災計画にそれぞ れ相当するであろう。最後に，アメリカ赤十字社による 個人や企業向けの災害チェックリストを紹介寸る。

\section{2.アメリカ合衆国国土安全保障省の国家対応計画}

アメリカ合衆国国土安全保障省 (U.S. Department of Homeland Security, 略称 DHS）は, アメリカ合衆国連邦政 府の組織の 1 つで，2002 年に設立された。この機関は米 国で 3 番目に大きい政府機関で，内部組織は多岐にわた る。DHS で扱われる 1 つの分野が「緊急事態への準備・ 対応」で，連邦緊急事態管理庁（FEMA）はその 1 つの 組織として組み込まれている。

DHS は2003 年に国家対応計画 ${ }^{2)}$ (National Response Plan, 略称NRP, 図 1）を発行し, 定期的に更新している。NRP の開発と更新については FEMA が深く関与している。

NRP の序文には, 「関係する国家機関の努力は, テロや 大きい災害などの緊急事態に対するアメリカの脆弱性を 低減するとともに，攻撃や大きい災害などの緊急事態か らの被害を最小限にし, 復旧する。」書かれており, 2001

* 京都大学防災研究所 - 研究員

Researcher, Kyoto University, Disaster Prevention Research Institute 
年9月 11 日のニューヨークでのテロ被害がかなり意識さ れている。NRPの目的は, 「予防, 準備, 対応および復旧 を含む活動を横断する自国の突発事態の管理に対する広 範囲の国家的なすべてのハザードのアプローチを確立す ること」である。NRP の範囲は,「テロや大きい災害など の緊急事態の劦威や行為に対する対応に, 複雑でしきり に変化する要求の範囲全体を前もってカバーする」とし ている。

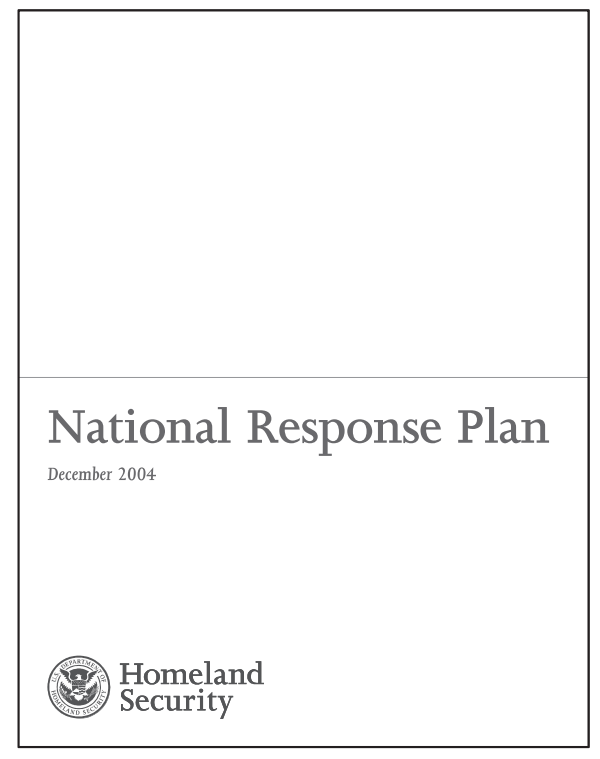

図 1 アメリカ合衆国国土安全保障省国家対応計画

3.フロリダ州広域緊急管理計画

NRP が国家の安全保障についての対応計画であるのに 対し, 州や郡単位で緊急管理計画が作成されている。こ こでは，ハリケーンの常襲地域であるフロリダ州の対応 マニュアルを䙼いてみよう。

フロリダ州広域緊急管理計画 ${ }^{3)}$ (The State of Florida Comprehensive Emergency Management Plan, 図 2) は, フ ロリダ州緊急管理部によって作られている。この計画は, 前に述べた国家対応計画に呼応し，災害に対する活動が 連邦政府と同時に進行するように調整されている。計画 は緊急管理の 4 つのフェーズ (準備, 対応, 復旧および 減災) での行動目標と目的を明確にしている。

この計画では, フロリダ州に発生する 7 つの脅威につ いて過去のデータから危険性評価を行なっている。脅威 は,

1）熱帯性サイクロン

2) トルネード

3）環境イベント（山火事, 冬季ストーム, 洪水, 熱波,
エルニーニョ）

4) 微生物イベント（動物の病気, 流行性寄生)

5) テロリズム（サイバーテロ含）

6) 技術的イベント (原子力発電所, 危険物質, 航空機 のクラッシュ)

7) 移民

である。熱帯性サイクロンについての影響は，人口，財 産およひ環境の観点では脆弱性指標が最も高い「荒廃的」, 行政の活動の観点では「高い」にランクされている。ま た, トルネードについては, 人口, 財産の観点では「普 通」, 環境の観点では「高い, 行政の活動の観点では「低 い」にランクされている。このように, 考えられる脅威 (災害) に対して影響度を定量的に評価している。

緊急管理の基本的な目標は, 災害によって作られる結 果一の対応と復旧への準備を確実にすることとしている。 熱帯性サイクロンによって作られる問題には, 大規模脱 出, 避難 (事前および事後), 脱出・避難および処分に伴 う動物の問題, インフラの被害や損失（下水，水道，電 気, 道路, 橋, 瓦碩, 通信等), 財政機構の被害や損失, サービス業の被害や損失, 作物の損失, 財産の損失, 長 期間の経済的インパクト, 経済的社会的混乱, 広範囲の 心理的インパクト, 復帰が挙げられている。同様に、ト ルネードに伴う問題としては, 停電, インフラ被害（道 路・排水溝の洗い流し, 水・ガス・通信ラインの破壊), 浸食, 旱䰠, 住家の火事, 動物の脱出 - 避難 - 処分等, 洪水, 高潮, 道路の水結, 脱出 (昼夜), 山火事, 作物被

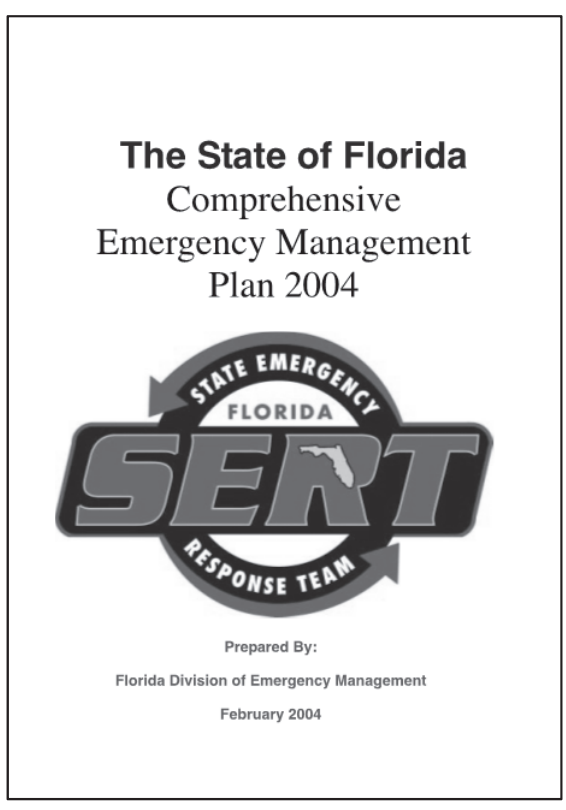

図 2 フロリダ州広域緊急管理計画 
害, 経済的損失や企業の中断, 財産の損失, 経済的損失, 瓦碩，道路の混雑，復帰が挙げられている。

災害の大きさは, 次の「小」,「大」,「荒廃的」の 3 つ のレベルに分類される。

1) 小災害 : 地方行政の対応能力内にあり, 州または連 邦の支援を最小限にのみ必要とする災害

2) 大災害 : 地方の能力を超え, 州の広い範囲と連邦の 支援を要請する災害。連邦の支援は対応と復旧の二 ーズを含む。

3) 荒廃的災害: 直後の軍隊の参加を含屯州と連邦から の大量の支援を要請する災害。連邦の支援は対応と 復旧のニーズを含む。

対応の責任は，郡，特別地区，州政府，連邦政府に分 けて決められているが，どのような災害に対応するとき も「最も近い適切な対応者 (closest appropriate responder)」 の概念を使う，と書かれている。多くの場合，郡は災害 の最初で基本的な対応者であり, 州の支援を要請する前 に郡で準備した資源を使い果たすこともできる。州と連 邦政府は災害の規模に応じて郡に支援を提供する。

郡の第 1 対応者としての責任は重要であると思われる ので，詳しく見ると，次のようにまとめられている。

1) 郡内の広域緊急管理システムに責任をもつすべての 行政，私的およびボランティア組織を含む郡レベル での緊急管理プログラムを維持すること。

2) 郡内の寸べての地方自治体の緊急管理の必要性と緊 急支援に応えるための郡相互救援協定を確立するた めの作業。

3）郡のすべての市民に届くように設計された広報，教 育および情報プログラムを実行すること。それには， 特別なメディア, 非英語会話者 (第一言語として英 語を使わない人々を含む）と聴覚障害者の様式を必 要とする。

4) 郡の能力を超えた状況における州内の相補緊急救助 支援のための相互救援協定を結ぶこと。

5) 政策，基準および規則の施行を通して災害の影響を 避け，低減し，軽減するために計画された緊急管理 プログラムを維持する。

6) 相互救援協定の結果として移動された資源を含む, 災害に伴う費用と経費を管理する。

7) 緊急事態の間に公的情報活動を調整する。

8）自身の行政区画内の避難民と州からの支援を受けて 外部からの避難民を受け入れる手順を開発し，管理 すること。

9）住民に警告を発する能力と 24 時間警報局を維持し
運営する郡の能力を確実にすること。

州は, 緊急事態が発生すると, 州緊急オペレーション・ センターを拠点にした州緊急対応チームを編成し, 活動, 情報および計画, 法の執行, 後方支援および普及経過の 5 つの機能ごとに既存の組織を割り当てていく。組織内の 部署にどの機能を担当させるかではなく, 機能（必要な 活動）に合わせて部署を決定する方法によって，行動の 迅速性と一貫性が確保できると思われる。

準備, 対応, 復旧および咸災の 4 つのフェーズについ ての実際の活動は，それぞれの目標を作り，それを実現 するための計画を立て, 実行し, 計画を定期的に見直し て更新していくプロセスを経る。

準備フェーズでは，基金，公共教育，資源管理，シェ ルター不足の解消，避難，住民警告周知の目標を掲げて いる。対応フェーズの目標は災害の前後 72 時間を 24 時 間ごとに区切り，行動目標が示されている。復旧フェー ズでは最初の 24 時間以内の被災者の支援とその後の個人 と企業の復旧努力を支援するために災害復旧センターを 確立するとしている。減災フェーズでは，災害に対する 脆弱性を低減する種々の目標が示され, 減災プログラム が作られる。

\section{Dade 郡広域緊急管理計画}

マイアミ Dade 郡広域緊急管理計画 ${ }^{4)}$ (Miami-Dade County, Florida Comprehensive Emergency Management Plan, 略称 CEMP, 図 3）は, フロリダ州の広域緊急管理計画と 連動して機能するように意図して作られており，地域の 状況に応じた詳細で具体的な計画となっている。

この計画では, Dade 郡の人口構成を調べ, 年齢, 性, 民族, 家族構成, 職業, 言語別などで表に示されている。 また，障害をもつ人々の数が，それぞれの障害の種類 (例 えば, 難聴, 視覚障害, 認知症, 歩行困難など) ごとに 年齢区分とともに示されている。災害は，「事故」，「小災 害」,「大災害」および「荒廃的な災害」の 4 段階に分け られ，対応と復旧の分類がなされている。例えば対応で は, 「事故」の場合通常 1,2 の地方局が, 「小災害」では通 常 2,3 の地方局のみが対応し,「大災害」では地方の局を 超える資源の要求が出され相互救援を必要とする。「荒廃 的な災害」では地方の資源を大きく超え広範囲の相互救 援と支援が要求されるとしている。

Dade 郡内の警察署, 消防署, 病院 (図 4), 橋, 運河, 高潮ゾーン，モービルホーム公園，原子力発電所の警報 サイレン, 基本避難ルート（図 5）などがマップに示され ている。ハリケーンからの避難は, 高潮ゾーンから約 58 
万人 (郡の人口約 250 万人) が発生すると予想している。

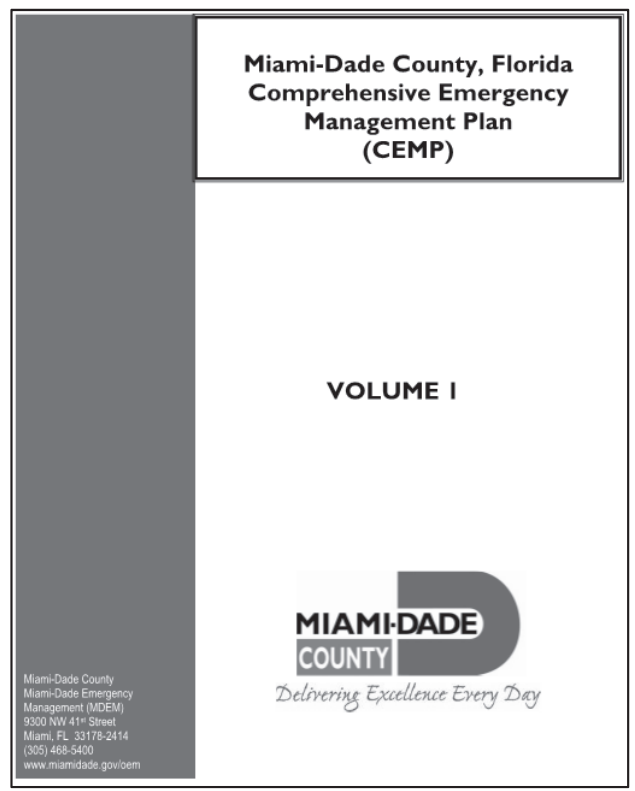

図 3 マイアミ Dade 郡広域緊急管理計画

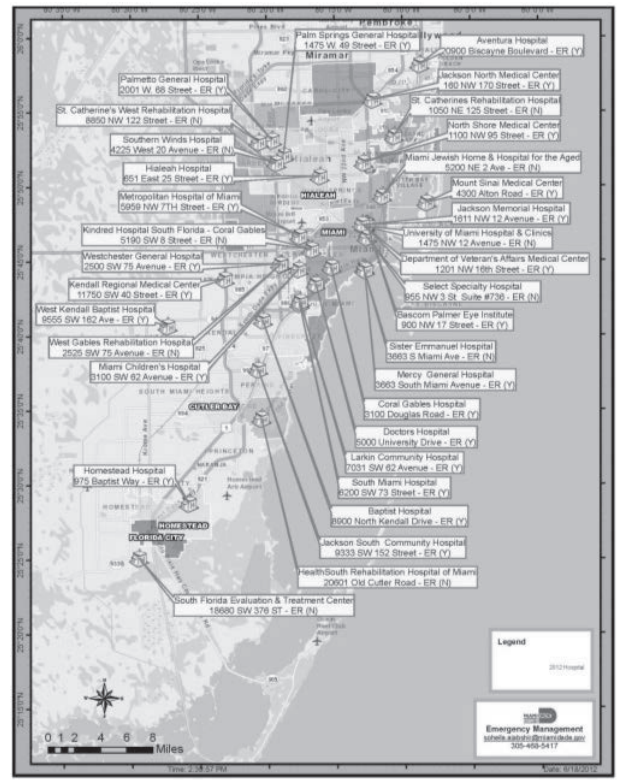

図4 マイアミ Dade 郡病院マップ(CEMP)

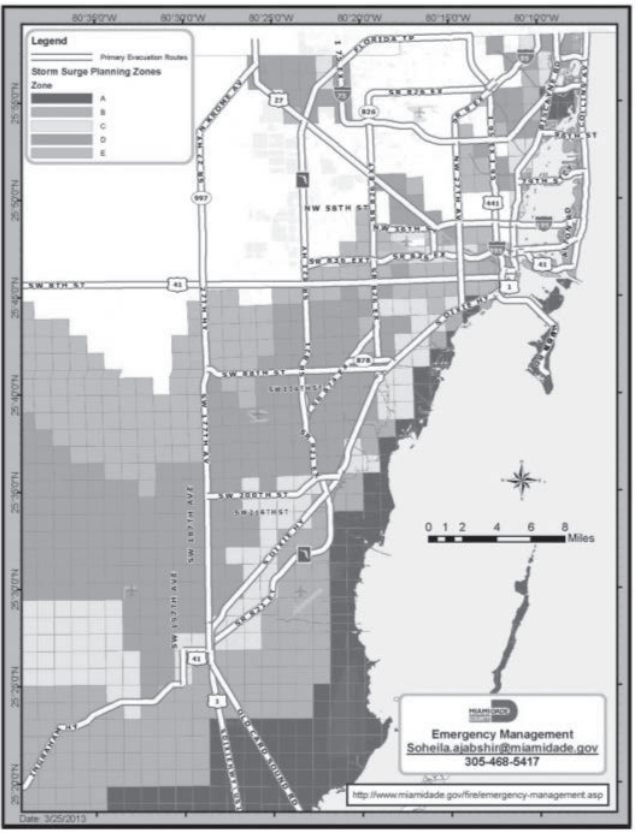

図 5 マイアミ Dade 郡基本避難ルート(CEMP)

5.アメリカ赤十字社のリーフレット

アメリカ赤十字社は, 八リケーン, トルネード, 地震, 津波などの自然災害ごとに個人の行動を簡単にまとめた リーフレット5)を公表しており, 行動チェックリスト (図 6）も用意している。本研究会では，これらのチェックリ ストを参考にして，わが国用の個人向け「竜巻安全チェ ックリスト」と「台風による強風への安全チェックリス 卜」を作成したのである。

リーフレットは，家族，学校，企業向けに別々に作成 されている。また，日頃準備しておくべき応急キットの リスト，災害時のペットに対する注意，障害をもつ人々 や支援者向けにも必要なことを詳しく解説している。子 供向けには，ディズニーのキャラクターを用いた教育用 の電子本がホームページに用意され，クイズを楽しみな がら災害の準備についての知識が得られる工夫もなされ ている。

これらの充実した情報発信は，社会啓発や教育に効果 的であると思われる。これらに類似したものを，強風災 害をテーマのひとつとする日本風工学会だけで作ること ができるものではないが，広い呼び掛けがあった際には， 協力できるようにしておきたいものである。

\section{6.まとめ}

本研究会で参考とした米国の緊急対応計画について簡 単に述べた。その全体像はあまりに大きく，ごく一部し 
か垣間見ることができなかったが，それでも，情報発信 の重要性を知ることができる。

アメリカ合衆国国土安全保障省や FEMA はモデル緊 急対応計画を作成し，連邦，州，郡単位ではそれぞれの 地域で特徵的な自然災害対応計画を取り入れて，具体的 な対応マニュアルを作成している。印象的であったのは, わが国の防災計画が既存の組織の中に対応する部署を割 り付けているのに対し，米国では災害への必要な対応項 目ごとに，各部署を割り付けていることであった。緊急 事態に対して迅速な対応をとるためには，命令系統を明 確にして一元的に管理することが望ましいと思われる。

個人対応マニュアルについては，アメリカ赤十字社が 各種のリーフレットやチェックリストを公表しており，
本研究会の参考になった。災害時要支援者に対して十分 な配慮を行なうことは必要であると思われる。

参考文献

1）一般社団法人日本風工学会風災害研究会, 「強風㷋害 の変遷と教訓第2 版 (2011)」, (2011.12)

2) Homeland Security, "National Response Plan", (2004.12)

3) Florida Division of Emergency Management, "The State of Florida Comprehensive Emergency Management Plan 2004", (2004.2)

4) Miami-Dade County, Miami-Dade County, "Florida Comprehensive Emergency Management Plan”, (2013.6)

5）アメリカ赤十字社, http://www.redcross.org

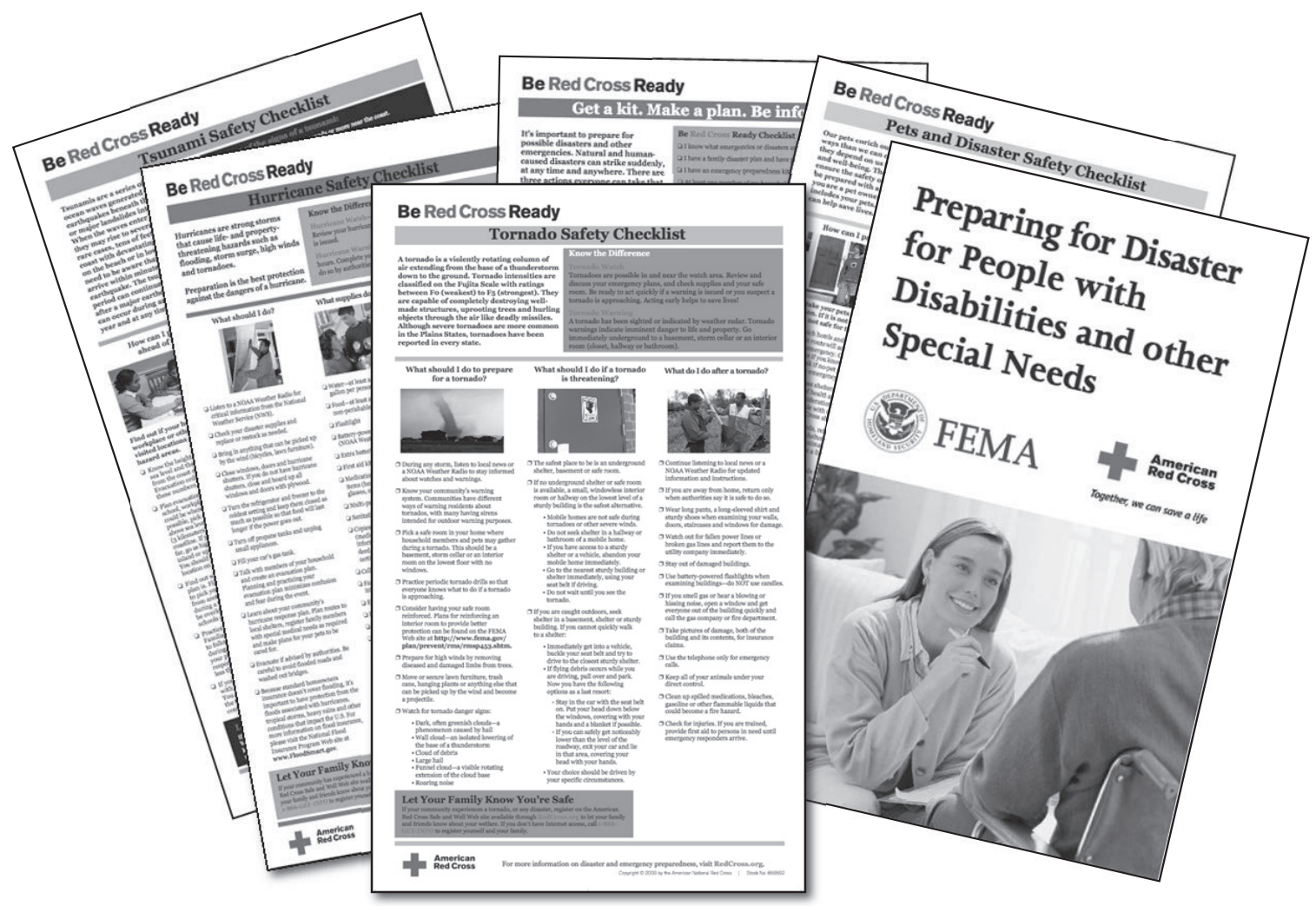

図 6 アメリカ赤十字社が発行する各種のリーフレットとチェックリスト 